\title{
Increasing the parameters of electrical distribution networks of town districts with low load density
}

\author{
V. Perepechenyi \\ O.M. Beketov National University of Urban Economy in Kharkiv, \\ Ukraine \\ E-mail: jahoma@i.ua
}

\begin{abstract}
This article presents the results of research on the parameters of electrical networks with a voltage of 6 (10) and $0.38 \mathrm{kV}$ in relation to capital investments. The analysis of existing methods of estimation of parameters before designing for power supply networks in a small town with low load density is carried out. In modern conditions, in the distribution of electrical networks is of paramount importance the introduction of energy-saving schemes and parameters of power supply systems. One of the main ways to implement them is to increase the efficiency of 6-10 / 0.38 kV networks. In the actual design of electrical networks, economic proportionality can not always be maintained for various reasons: the impact of technical constraints, the discreteness of the rated power of transformers and cable crossing scales, a significant deviation of individual capacities of consumers from the average value. In that case there is an increase in the reduced costs. A methodology for determining the optimal power of transformer substations and optimal sections of $0.38 \mathrm{kV}$ power transmission lines is proposed, taking into account the probable nature of the applied load. When assembling the power supply circuit for the optimal form of parameters, voltage, principles of voltage regulation and reactive power compensation. Decisions of this kind are substantiated by technical and economic comparisons of a series of technically acceptable variants of power supply networks. An important measure that facilitates the selection of the most economical option is the assessment of the proposed project, which relates to the selection of the optimal capacity of transformer substation (TS) networks using calculation formulas. The aim of the research was to improve the existing methods on the basis of separate accounting of the reliability coefficient of $0.38 \mathrm{kV}$ and $6-10 \mathrm{kV}$ network.
\end{abstract}

Key words - electric power supply network, network parameters, transformer substation, load density, line wire section, specific load, unit costs, optimum parameter, distribution networks, electric energy.

\section{INTRODUCTION}

In modern conditions, the electric power industry plays a paramount role in the social and economic development of society, and determines the level of economic security of states. Under these conditions, solving the problems associated with saving material and energy resources acquires a special role. This primarily relates to the use of energy-saving equipment and circuits of power supply systems (PSS), which reduce the cost of building a PSS, transfer and distribution of electric energy (EE) in its networks, reduce voltage and power losses in networks, improve quality (IQ) consumers.

This is accompanied by the following main reasons:

- significantly increased the power consumption of power receivers and the length of the distribution networks
(DN), due to the expansion of the scope of energy efficiency in everyday life, utilities and municipal services;

- the role of economic responsibility for the level of investment and compliance with the GOST indicators established by GOST due to the introduction of market relations in the energy sector has increased;

- the working conditions of networks caused by their fragmentation and municipalization have worsened;

- the conditions for regulating the voltage in the networks are complicated, due to the presence of a large number of different parameters and modes of power receivers;

- network design conditions have become more complicated due to an increase in the level of uncertainty of the source data.

As a result, having extensively branched, extended distribution networks combined with a low level of quality of design solutions, Ukrainian cities found themselves in a rather difficult situation caused by a shortage of material, fuel and energy resources. In these conditions, the introduction of energy-saving schemes and parameters of PSS, which provide cost reduction, quality improvement and reduction of energy efficiency during transport, is of paramount importance. One of the main ways of their implementation is to increase the efficiency of 6-10 / 0.38 $\mathrm{kV}$ networks. According to the results of studies [1-4], one of the most important directions for increasing the efficiency of DN cities is the optimization of their structures and parameters. As cities develop, the improvement of the structure of PSS is carried out by introducing additional links - medium and higher voltage supply and distribution networks, switching to a higher voltage, etc. However, the possibilities of improving the structures and parameters of PSS in cities are currently almost exhausted due to the limited range of energy equipment.

The purpose of the work - optimization of parameters of distribution electric networks of settlements with low density of loading.

\section{BASIC MATERIAL}

When compiling the electric power supply circuit for optimum shape, parameters, voltage, voltage adjustment principles and reactive power compensation. Solutions of such a kind are substantiated by feasibility comparisons of a series of technically acceptable variants of electric power supply networks. An important measure that facilitates a choice of the most economical variant is the pre-design estimation dealing with a matter of chosing the optimum 
power of network transformer substations (TS) by means of calculation formulae.

Available calculation formulae for TS optimum power determination in districts with few-storeyed buildings are obtained by minimizing the equations of unit costs or capital investments using specific indices of load, which characterize its density on the territory under consideration.

In the capacity of specific indices we adopted the surface density of load $\sigma\left(\mathrm{k} V \cdot \mathrm{A} / \mathrm{ga} ; \mathrm{k} V \cdot \mathrm{A} / \mathrm{km}{ }^{2}\right)$, or linear density of load $\delta(\mathrm{kV} \cdot \mathrm{A} / \mathrm{km} ; \mathrm{kV \kappa B} \cdot \mathrm{A} / \mathrm{m})$, for determination of which it is necessary to know the summary length of streets. To determine the surface are of buildings or summary length of streets is not a large job as such.

However, design load of utility service users depends on a nature of users and their number which are connected to the TS-line. Generally, this relationship lodes as follows:

$$
S_{p}=S_{y \partial} \cdot k_{O \partial H} \cdot n
$$

where: $n$ - number of users; $S_{y \partial}$ - specific loads of particular users, $\kappa V \cdot A ; k_{o \partial H^{-}}$simultaneity coefficient that may be represented as a function of the number of users as follows:

$$
k_{\text {одн }}=a_{H}+\frac{b_{H}}{\sqrt{n}},
$$

where: $a_{H}$ and $b_{H}$ - interpolation coefficients.

Hence, the design load consumed by utility service users within a settlement town or by a group of users will be equal to:

$$
S_{p}=S_{y \partial} \cdot\left(a_{H} \cdot n_{\Sigma}+b_{H} \cdot \sqrt{n_{\Sigma}}\right)
$$

where: $n_{\Sigma}$ - the summary number of users.

When calculating design formulae for determination of TS optimum power rating as above, we made the TS is determined by the formula

$$
S_{T \Pi}=\frac{S_{p}}{N}
$$

where: $\mathrm{N}$ - number of transformer substations TS.

Load of the $0.38 \mathrm{kV}$ line is determined by the formula

$$
S_{\pi}=\frac{S_{T \Pi}}{m},
$$
TS.

where: $\mathrm{m}$ - number of $0.38 \mathrm{kV}$ lines going out from the

As we can observe in both cases an influence of the simulataneity coefficient is not taken into consideration the latter depending on the number of users connected to the TS or power transmission line.

As it can be seen from calculations an error in determining the optimum load of TS may make up 10\% up to $20 \%$ when we use the design load of a district (settlement), where as an error in determining the section of
$0.38 \mathrm{kV}$ lines makes up $20 \%$ up to $40 \%$ with the number of users in the district (settlement) laying within 500-1500.

All the above mentioned errors will be growing with an increase of $n_{\Sigma}$.

Complicated relationship between the number of users connected to TS-s and $0.38 \mathrm{kV}$ lines and power rating of transformers to be installed at TS-s does not allow to introduce a correction coefficient.

A fewer error will be provided with the methodology of network optimum parameters determination after having determined preliminary an optimum number of users to be connected to one TS, by using here at as initial data density of users distribution over a territory or street-by-street and specific load of particular users.

Number and summary length of power transmission lines in a settlement with few-storeyed buildings is changing insignificantly with a change of substations number. Therefore we assume their total extent one TS service zone to:

$$
L_{H}=l_{0} \cdot n_{\pi} \cdot m
$$

where: $l_{0}$ - average distance between users, $\mathrm{km} ; n_{\pi}$ number of users connected to one line; $m$ - number of lines outgoing from TS.

Under real conditions, density and nature of users location may be extremely different. To generalize investigations some idealization of the network lay-out is inevitable. Since such idealization covers the particular district for some variants of electric power supply networks, then the inaccuracy assumed for another variant would be also allowable for another variant hence both variants will be of the same errors.

If we consider the $0.38 \mathrm{kV}$ line as a main line with taps where distance between loads taken up and section over the whole length are invariable supposing that the taps are evenly distributed along the main line then we can obtain the linear moment for such a line as follows

$$
M_{\pi}=S_{\pi} \cdot l_{0} \cdot n_{\pi} \cdot k_{H},
$$

where: $k_{H}$ - coefficient of loads distribution in terms of voltage.

Coefficient of loads distribution in terms of voltage for this model line would be equal to:

$$
k_{H}=\frac{0.5}{1+\alpha_{M}},
$$

where: $\alpha_{M}$ - number of loads at the branch line in relation to their total number connected to the line. Power losses within the line would be equal to:

$$
\Delta W_{л}=\frac{S_{\pi}^{2} \cdot \rho \cdot \tau \cdot 10^{-3}}{U_{H}^{2} \cdot k_{e}^{2} \cdot F} \cdot l_{0} \cdot n,
$$

where: $\rho$ - specific resistance of wire material, $O m \cdot \mathrm{mm}^{2} / \mathrm{km} ; \tau$ - time of maximum losses, $h /$ year $; U_{H}$ nominal voltage in the network, $\mathrm{kV} ; F$ - section of wires, 
$\mathrm{mm}^{2} ; k_{e}$ - coefficient of loads distribution in terms of power rating, which may be defined with an accuracy up to $10 \%$ for this model line under consideration by the formula:

$$
k_{e}=1.58 \cdot\left(1+\alpha_{\mathcal{M}}\right),
$$

On assumption that the lines outgoing from TS are loaded with the equal number of loads with $\mathrm{m}$ - being number of lines the load at one line would be equal to:

$$
S_{\pi}=S_{y \partial} \cdot\left(\frac{a_{\mu} \cdot n_{T \Pi}}{m}+\frac{b_{\mu} \cdot \sqrt{n_{T \Pi}}}{\sqrt{m}}\right),
$$

where: $n_{T \Pi}$ - number of loads connected to TS.

In order to obtain the minimum of unit costs within the network for $0.38 \mathrm{kV}$, section of lines shall be selected on the basis of economics reasons, i.e. based on an economical density of current $\left(j_{e}\right)$.

$$
F_{1}=\frac{S_{\pi}}{\sqrt{3} \cdot U_{H} \cdot k_{e} \cdot j_{e}},
$$

The section chosen should satisfy requirements of technical constraints. Technical constraints in branched non-redundancy distributive networks are: mechanical strength and admissible voltage loss $\Delta U_{\partial}$. In case of overhead lines minimum section of aluminum wire because of mechanical strength makes up $F_{2}=16 \mathrm{~mm}^{2}$.

Section determined on the basis of an admissible voltage loss $\left(\Delta U_{\partial} \%\right)$, is:

$$
F_{3}=\frac{S_{\pi} \cdot \rho \cdot l_{0} \cdot n_{T \Pi} \cdot k_{H} \cdot \xi}{10 \cdot U_{H}^{2} \cdot \Delta U_{\partial} \% \cdot m},
$$

where: $\xi$ - coefficient that characterizes resistance of wires and load power factor,

$$
\xi=\cos \varphi+\frac{x_{0}}{r_{0}} \cdot \sin \varphi,
$$

In case of $0.38 \mathrm{kV}$ overhead networks $\xi \cong 1.05$ with $\cos \varphi=0.95$.

To find out application fields of the formulae for choice wire section on the basis of $j_{e}, \Delta U_{\partial} \%$ and mechanical strength, we will treat

$$
F_{2}=F_{1} ; \quad F_{1}=F_{3} \text { and } F_{2}=F_{3} \text { as identical. }
$$

Selection of wire sections in lines $0.38 \mathrm{kV}$ is reasonably to be performed by (12) with the number of loads at one line being

$$
n_{\pi} \geq\left(-\frac{b_{H}}{2 \cdot a_{H}}+\sqrt{\frac{b_{H}}{4 \cdot a_{H}^{2}}+\frac{\sqrt{3} \cdot F_{2} \cdot U_{H} \cdot k_{e} \cdot j_{e}}{S_{y \partial} \cdot a_{H}}}\right),
$$

and with the line length being

$$
n_{\pi} \cdot l_{o} \leq \frac{10 \cdot U_{H} \cdot \Delta U_{\partial} \%}{\sqrt{3} \cdot \rho \cdot j_{e} \cdot k_{H} \cdot k_{e} \cdot \xi},
$$

Selection of wires, based on $\Delta U_{\partial} \%$, is reasonably to be performed using:

$$
n_{\pi} \cdot l_{o} \geq \frac{10 \cdot U_{H} \cdot \Delta U_{\partial} \%}{\sqrt{3} \cdot \rho \cdot j_{e} \cdot k_{e} \cdot k_{H} \cdot \xi}
$$

and

$$
n_{\pi} \cdot l_{o} \geq \frac{10 \cdot U_{H}^{2} \cdot \Delta U_{\partial} \% \cdot F_{2}}{\rho \cdot \xi} .
$$

An analysis of application field for different ways of choosing wire sections for power transmission lines on reinforced concreted supports has revealed that with the $n_{\pi} \cdot l_{o}$ being up to $1 \mathrm{~km}$, it is reasonable to choose the wire section using the term $j_{e}$.

Taking all the above into account, unit costs for the $0.38 \mathrm{kV}$ network may be represented-provided that $F$ is determined in terms of $j_{e}$ - as:

$$
\begin{aligned}
3_{H н} & =\left[p_{\Sigma л} \cdot K_{\pi}^{\prime} \cdot l_{0} \cdot n_{T \Pi}+\right. \\
& +2 \cdot \frac{S_{y \partial} \cdot\left(\frac{a_{H} \cdot n_{T \Pi}}{m}+\frac{b_{H} \cdot \sqrt{n_{T \Pi}}}{\sqrt{m}}\right)}{U_{H} \cdot k_{\ni}} \times \\
& \left.\times \sqrt{p_{\Sigma} \cdot K_{\pi}^{\prime \prime} \cdot \rho \cdot \tau \cdot c_{e} \cdot 10^{-3}} \cdot l_{0} \cdot n_{T \Pi \Pi}\right] \cdot N,
\end{aligned}
$$

where: $p_{\Sigma \tau}$-subscriptions for amortization, repair and maintenance of $0.38 \mathrm{kV}$ lines, c.u.; $c_{e}-$ cost of lost electric power, $U A H / k W \cdot h ; K^{\prime}$ and $\mathrm{K}^{\prime \prime}$ - those cost fraction of 1 $\mathrm{km}$ line that depends on and does not depend on the wire section, $U A H / \mathrm{km}, U A H / \mathrm{km} \cdot \mathrm{mm}^{2}$.

$$
\begin{aligned}
3_{H н}= & {\left[p_{\Sigma \pi} \cdot K_{\pi}^{\prime} \cdot l_{0} \cdot n_{T \Pi}+p_{\Sigma л} \cdot K_{\pi}^{\prime \prime} \times\right.} \\
& \times \frac{S_{y \partial} \cdot\left(\frac{a_{H} \cdot n_{T \Pi I}}{m}+\frac{b_{H} \cdot \sqrt{n_{T \Pi}}}{\sqrt{m}}\right) \cdot \rho \cdot l_{0}^{2} \cdot n_{T \Pi}^{2} \cdot k_{H} \cdot \xi}{U_{H} \cdot k_{\ni}}+ \\
+ & S_{y \partial} \cdot\left(\frac{a_{H} \cdot n_{T \Pi}}{m}+\frac{b_{H} \cdot \sqrt{n_{T \Pi}}}{\sqrt{m}}\right) \times \\
& \left.\times \frac{m \cdot \tau \cdot c_{e} \cdot \Delta U_{\partial} \% \cdot 10^{-2}}{k_{e}^{2} \cdot k_{H} \cdot \xi}\right] \cdot N
\end{aligned}
$$

on provision that $F$ is determined in terms of $\Delta U_{\partial} \%$.

Unit costs for election and operation of TS make up:

$$
{ }^{3} T \Pi=\left[\left(p_{H}+p_{T \Pi}\right) K_{T \Pi}+\Delta W_{T X} \cdot c_{e}^{x}+\Delta W_{T K} \cdot c_{e}^{\kappa}\right] \cdot N,
$$

where: $K_{T \Pi}$ - capital investments into TS-s, UAH; $\Delta W_{T X}$ - electric power loss in transformer steel, $\mathrm{kW}$; $\Delta W_{T X}=\Delta P_{X} \cdot T_{B} ; \Delta W_{T K^{-}}$electric power loss in 
transformer windings, $\mathrm{kW} ; \quad \Delta W_{T K}=\Delta P_{K} \cdot\left(\frac{s_{p}}{S_{H}}\right)^{2} \cdot \tau$; $c_{e}^{x}, c_{e}^{\kappa}$ - costs of lost electric power, $U A H / k W \cdot h ; S_{p}, S_{H}$ - design load and nominal load of transformers, $k V \cdot A ; T_{B}$ - time of transformer switched-on state, $y \cdot h$.

Assuming that unit costs for the network are equal to the sum of costs for the TS and $0.38 \mathrm{kV}$ network and expressing them in relation to the unit of $0.38 \mathrm{kV}$ network length, i.e. $3_{c y \partial}=\frac{3_{c}}{l_{0} \cdot n_{T \Pi} \cdot N}$ and making use of designations

$$
\begin{gathered}
\left(p_{H}+p_{T \Pi}\right) \cdot K_{T \Pi}+\Delta W_{T X} \cdot c_{e}^{x}+\Delta W_{T K} \cdot c_{e}^{\kappa}=A_{1} \\
p_{\Sigma л} \cdot K_{ת}^{\prime}=B ; \\
\frac{2}{U_{H} \cdot k_{e}} \cdot \sqrt{p_{\Sigma \pi} \cdot K_{\pi}^{\prime \prime} \cdot \rho \cdot \tau \cdot c_{e} \cdot 10^{-3}}=C_{1} ; \\
\frac{p_{\Sigma л} \cdot K_{\pi}^{\prime \prime} \cdot \rho}{10 \cdot U_{H}^{2}}=D_{1} ; \\
\tau \cdot c_{e} \cdot 10^{-2}=E_{1} ;
\end{gathered}
$$

we obtain

$$
3_{c y \partial}=\frac{A_{1}}{l_{0} \cdot n_{T \Pi}}+S_{y \partial} \cdot\left(\frac{a_{H} \cdot n_{T \Pi}}{m}+\frac{b_{H} \cdot \sqrt{n_{T \Pi}}}{\sqrt{m}}\right) \cdot C_{1}+B_{1},
$$

provided that $F$ is determined in terms of $j_{\ni}$, and

$$
\begin{aligned}
3_{c \text { уд }} & =\left[A_{1}+E_{1} \cdot \frac{S_{y \partial} \cdot\left(a_{H} \cdot n_{T \Pi}+b_{H} \cdot \sqrt{n_{T \Pi} \cdot m} \cdot \Delta U_{\partial} \%\right)}{k_{e}^{2} \cdot k_{H} \cdot \xi}\right] \times \\
& \times \frac{1}{l_{0} \cdot n_{T \Pi}}+D_{1} \cdot S_{y \partial} \cdot\left(\frac{a_{H} \cdot n_{T \Pi}}{m^{2}}+\frac{b_{H} \cdot \sqrt{n_{T \Pi}}}{m \cdot \sqrt{m}}\right) \times \\
& \times \frac{k_{H} \cdot \xi}{\Delta U_{\partial} \%} \cdot l_{0} \cdot n_{T \Pi}+B_{1},
\end{aligned}
$$

provided that $F$ is determined in forms of $\Delta U_{\partial} \%$.

Relationships $3_{c \text { уд }}=f\left(l_{0}\right)$ are given at Fig.1 for specified initial data.

$$
3_{c y \partial 1}=3_{c y \partial 2} \text {, }
$$

where indices 1 and 2 belong to configure power transformer substations.

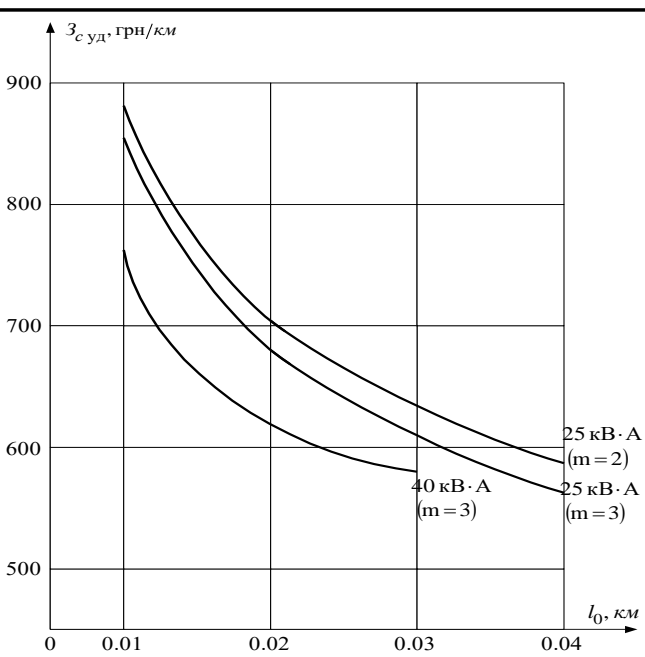

Fig. 1. Relationship $3_{c y d}=f\left(l_{0}\right)$ for complete TS-s and $0.38 \mathrm{kV}$ lines installed on reinforced concrete supports

\section{CONCLUSIONS}

The article considers the issues of increasing the parameters of electrical distribution networks of settlements with low load density.

Based on the above, we can draw the following main conclusions:

1. Analysis of curves, see Fig. 1 reveals that the extent of $0.38 \mathrm{kV}$ power transmission lines acts as a constraint factor in the process of chosing transformer substations TS of great power rating.

2. The study of the parameters of the distribution electric networks of low-rise areas has established the optimal distance between consumers and the optimal power of transformer substations, providing optimal network conditions. As limiting factors, the length of low voltage lines is proposed, which should not exceed $1 \mathrm{~km}$.

\section{REFERENCES}

[1] Zorin V.V., Tretyakova L.D., Basam H. Multipurpose optimization of the dynamics of development of distribution electric networks // Energy and Electrification. 1991. No. 3. P. 5-10.

[2] Methods for ensuring uniform load distribution of transformers and feeders in Japan's urban electrical distribution networks. Aoki Kenichi, Kuwabara Heijiro, Satoh Taiji, Kanezashi Masakuzu. "Denki gakkay rhomboons. Trans. Inst. Elect. Eng. Jap. ", 1997, B 127, No. 7, 439-446 (Japan)

[3] A method for determining the optimal ratio between investments in new equipment and modernization of the old with the development of medium-voltage urban power networks. Optimum balance between structural and operating investments for development of radial MV networks / Messager P. // Bull.Dir.Etud.et rech.B., 2001. - No. 4. - P.36-47.

[4] Zuev E.N. Selection of the main parameters of power lines of district electric networks in modern conditions - M .: Informelectro, 2003.- 64 p. 


\title{
Підвищення параметрів електричних розподільних мереж міст в районах 3 низькою щільністю навантаження
}

\author{
В.О. Перепечений \\ ХНУМГ ім. О.М. Бекетова, \\ Україна
} У статті наведено результати досліджень параметрів електричних мереж напругою $6(10)$ та 0,38 кВ щодо
капітальних вкладень. Проведено аналіз існуючих методів оцінки параметрів перед проектуванням для мереж.

У сучасних умовах, в розподільних електричних мережах першорядне значення набувас впровадження енергозберігаючих схем і параметрів систем електропостачання. Одним з основних шляхів їх реалізації є підвищення ефективності роботи мереж 6-10/0,38 кВ.

При реальному проектуванні електричних мереж економічна соразмірність не завжди може бути витримана через різного роду причин: вплив технічних обмежень, дискретності номінальних потужностей трансформаторів і шкали перетину кабелів, значного відхилення одиночних потужностей споживачів від середнього значення. У цьому випадку відбувається збільшення приведених витрат.

Запропонована методологія визначення оптимальної потужності трансформаторних підстанцій та оптимальних ділянок ліній електропередачі 0,38 кВ 3 урахуванням імовірного характеру прикладеного навантаження. При складанні ланцюга живлення для оптимальної форми параметрів, напруги, принципів регулювання напруги та компенсації реактивної потужності. Рішення такого роду обгрунтовуються технікоекономічними порівняннями серії технічно прийнятних варіантів мереж електропостачання. Важливим заходом, що сприяє вибору найбільш економічного варіанту, с оцінка передбачуваного проекту, що відноситься до питань вибору оптимальної потужності мереж трансформаторних підстанцій (ТС) за допомогою формул розрахунку. Метою досліджень стало вдосконалення існуючих методів на основі окремого обліку коефіцієнта надійності мережі 0,38 кВ та 6-10 кВ Тут пропонується методологія визначення оптимальної потужності трансформаторних підстанцій та оптимальних ділянок $0,38 \mathrm{kB}$ лінії електропередачі з урахуванням імовірнісного характеру прикладеного навантаження.

Ключові слова- мережі електропостачання, параметри мережі, трансформаторна підстанція, щцільність навантаження, питоме навантаження, одиничні витрати, оптимальний параметр, розподільні мережі, електрична енергія. 